\title{
THE EFFECTIVENESS OF PROVIDING RACED CHICKEN EGGS ON THE NUTRITION FOR PREGNANT WOMEN IN CHRONIC ENERGY DEFICIENCY IN KENDARI CITY, SULAWESI, TENGGARA
}

\author{
Sitti Aisa ${ }^{1}$, Sunarsih $^{2}$, Nurmiaty $^{3}$ \\ ${ }^{1,2,3}$ College of Health Sciences Mandala Waluya Kendari, Southeast Sulawesi, Indonesia. \\ Corresponding Author : Sitti Aisa \\ Email : sittiaisakeb@gmail.com
}

\begin{abstract}
Background: Chronic Energy Deficiency (CED) of energy is a problem that is often encountered in pregnant women, this often occurs due to malnutrition in the long term, especially those related to carbohydrates and fats that are not consumed. Research purposes; For the effect of eating one egg a day on the nutritional status of pregnant women in CED in Kendari City, Southeast Sulawesi Province in 2020.
\end{abstract}

Methods: Using a quasi-experimental design, the total sample was 36 CED pregnant women, in the working area of Primary health care Nambo and Primary health care Abeli. Intervention Egg delivery was carried out for 8 weeks, measured LBW and BW every 2 weeks, measurements were carried out 5 times, namely before the intervention, after weeks 2, 4, 6 and 8. Data analysis used independent $t$ test, paired test and oneway statistical test. anova.

Result: Using the independent $t$ test, the results were there were no differences between the body weight (BW) and Upper Arm Circumference (UAC) interventions and the group before the study. Furthermore, the paired test results obtained differences in weight and LBW before and after offering eggs to the intervention group. There were differences in BW and UAC after offering eggs to The results of the independent $t$ test were obtained. There were differences in weight and UAC after offering eggs in the intervention group and the control group. The results of the analysis with the one-way aova test showed that the effective time of offering boiled eggs to increase body weight and UAC was the eighth week

Conclusion: There was no difference in weight and UAC in the intervention group and control group before the study, but there were differences in weight and LBW before and after egg administration in the intervention and control groups

Key words: Chicken eggs, nutrition of pregnant women, Chronic energy deficiency

Indonesian Journal Of Health Sciences Research and Development

Vol. 2, No. 2, October 2020 


\section{INTRODUCTION}

Chronic energy deficiency ( CED ) ) is a problem that is often found in pregnant women, this often occurs related to malnutrition in the long term, especially those related to carbohydrates and fats that are not consumed properly(1). Measurement of upper arm circumference ( UAC ) is performed to detect the risk of CED in pregnant women. If a pregnant woman experiences a UAC size of less than 23.5, then the pregnant woman is at risk of experiencing CED. CED can also be confirmed by measuring the body mass index (BMI). Pregnant women are diagnosed with CED in the first trimester of pregnancy. If you have a BMI of less than 18.5, then the mother is at risk of experiencing CED. However, usually women begin to become pregnant in the second or third trimester so that their pre-pregnancy weight and height can be used as pre-pregnancy BMI (2).

The risks that will be experienced by pregnant women in CED are miscarriage, puerperal bleeding, and maternal death(3). Meanwhile, fetuses and children include impaired fetal growth, risk of low birth weight (LBW), risk of babies with congenital abnormalities, and risk of stunting. This incident will be experienced since the baby is in the womb and will continue into adulthood(4).WHO has experienced CED problems in almost all developing countries such as Bangladesh, India, Indonesia, Myanmar, Sri Lanka and Thailand with a CED prevalence of $15-47 \%$. The prevalence of CED in pregnant women in Asia is as much as $20 \%$ (Black et al, 2008). Whereas in Indonesia alone the incidence of CED in pregnant women was $24.2 \%$ in 2013 and this risk decreased to $17.3 \%$ (5). The prevalence of pregnant women in CED based on profile data from Southeast Sulawesi was $22.5 \%$ in 2015 and decreased by $22.38 \%$ in 2017 . Kendari City, the number of pregnant women in CED was 12.3, the highest was Primary health care Nambo, namely $91.0 \%$ and the lowest is Primary health care Poasia as much as 3,6\%(6).
Primary health care Nambo not only has a high CED but also its condition which is located on the coast which contains a lot of protein from fish species. But the fact is that consuming protein from fish is not enough, so that pregnant women experience CED. In the second trimester, pregnant women need additional calories of $180 \mathrm{kcal} /$ day and in the second and third trimesters around 300 kcal / day. Nutrients that contain calories, such as carbohydrates, protein and fat. And dietary components which include vitamins and minerals. It is recommended that foods containing protein be consumed every day to meet the protein needs in the body. Because protein cannot be stored as a reserve(7).

Eggs are very good for consumption by mothers when they enter the second trimester of pregnancy, because besides containing protein they also contain calcium and vitamin D. Two nutrients that are mandatory for mothers to fulfill because the second trimester is a period of bone formation and teeth(8). Lack of calcium and vitamin D makes its growth imperfect, so that the fetus will be susceptible to various bone diseases. The results of Sugita and Supiati's 2016 research on anemic pregnant women stated that consumption of boiled eggs was effective in increasing $\mathrm{Hb}$ levels in pregnant women in the second trimester in the working area of Klaten Tengah Primary health care (9).

Based on the above background, the researchers wanted to provide additional food in the form of boiled eggs for CED pregnant women with a dose of one seed per day and given at night. Eating boiled eggs has many health benefits, compared to fried eggs. Boiling is one way to get optimal egg benefits. Because boiled eggs are the result of cooking that are not contaminated with other harmful substances. This study aims to determine the effect of giving one egg a day on the nutritional status of pregnant women in CED at Primary health care Nambo, Kendari City, Southeast Sulawesi Province in 2020. 


\section{METHOD}

The type of research used is experimental research with a quasiexperimental approach(10). In this design, there are two groups, each of which is randomly selected. The first group was given intervention and the other group was not given intervention(11). Intervention $\mathrm{Egg}$ delivery was carried out for 8 weeks, measuring LBW and BW every 2 weeks, measurements were carried out 5 times, namely before the intervention, after weeks 2, 4, 6 and 8. Kendari City in June to August 2020. The population in this study were all CED pregnant women in the working area of the Primary health care Nambodan Primary health care Abeli, Kendari City from January to May 2020. Nambo Primary health care total 46 people and Abeli Primary health care 28 people so the total population is 70 people. The sample size is 36 people. Data analysis used statistical test independent $t$ test, paired test and oneway anova.

\section{RESULT \\ Nutritional Status}

Based on grafic-1 above, it can be seen that the average body weight before the intervention in the intervention group was $50.78 \mathrm{~kg}$. Whereas in the control group the average body weight was $48.24 \mathrm{~kg}$. Two weeks after the intervention there was an increase in the average body weight of 1.37 $\mathrm{kg}$ in the intervention group, namely 52.15 $\mathrm{kg}$. Whereas in the control group there was an increase in the average body weight of $0.65 \mathrm{~kg}$, namely body weight to 48.89 $\mathrm{kg}$.Between the intervention group and the control group both experienced weight gain, but in the intervention group the weight gain was greater than the weight gain in the control group. Four weeks after the intervention, the average weight gain in the intervention group was $2.39 \mathrm{~kg}$, namely $53.17 \mathrm{~kg}$. Whereas in the control group the average body weight gain was $1.53 \mathrm{~kg}$, namely the body weight to $49.77 \mathrm{~kg}$. Both groups gained weight, but the intervention group gained more weight than the control group. Six weeks after the intervention, the average weight gain in the intervention group was $3.42 \mathrm{~kg}$, namely the body weight to 54.2 $\mathrm{kg}$. Whereas in the control group the average body weight gain was $2.46 \mathrm{~kg}$, namely the body weight being $50.7 \mathrm{~kg}$. Both groups gained weight, but the intervention group gained more weight than the control group. Eight weeks after the intervention, the average weight gain in the intervention group was $5.42 \mathrm{~kg}$, body weight was $56.2 \mathrm{~kg}$. Whereas in the control group the average body weight gain was $3 \mathrm{~kg}$, namely the body weight being $51.24 \mathrm{~kg}$. Both groups experienced weight gain, but the weight gain in the intervention group was greater than the weight gain in the control group.

Based on the figure above 42 , it can be seen that the average size of the LBW before the intervention in the intervention group was 21.5. Whereas in the control group the average body weight was $21.27 \mathrm{~cm}$. Two weeks after the intervention, it was seen that the average increase in LBW size was 0.58 $\mathrm{cm}$ in the intervention group, namely 22.08 $\mathrm{cm}$. Whereas in the control group the average increase in LBWsize was 0.16, namely 21.42 $\mathrm{cm}$. Both groups had an increase in LBW size, but the intervention group had a greater increase than the control group.Four weeks after the intervention it was seen that the mean increase in LBW size in the intervention group was 0.95 , that is, 22.45 . Whereas in the control group the average increase in LBW size was 0.57, namely $21.84 \mathrm{~cm}$. Both groups had an increase in the size of the LBW, but the intervention group had a greater increase than the control group. Six weeks after the intervention, it was seen that the average increase in LBW size in the intervention group was 1.25 , namely 22.75 $\mathrm{cm}$. Whereas in the control group the average increase in LBW size was 0.73, namely $22.00 \mathrm{~cm}$. Both groups had an increase in LBW size, but the intervention group had a greater increase than the control group. Eight weeks after the intervention, it was seen that the mean increase in LBW size in the intervention group was $1.62 \mathrm{~cm}$, namely 
$23.12 \mathrm{~cm}$. Whereas in the control group the average increase in LBW size was 1.22, namely $22.49 \mathrm{~cm}$. Both groups experienced an increase in LBW size, but the intervention

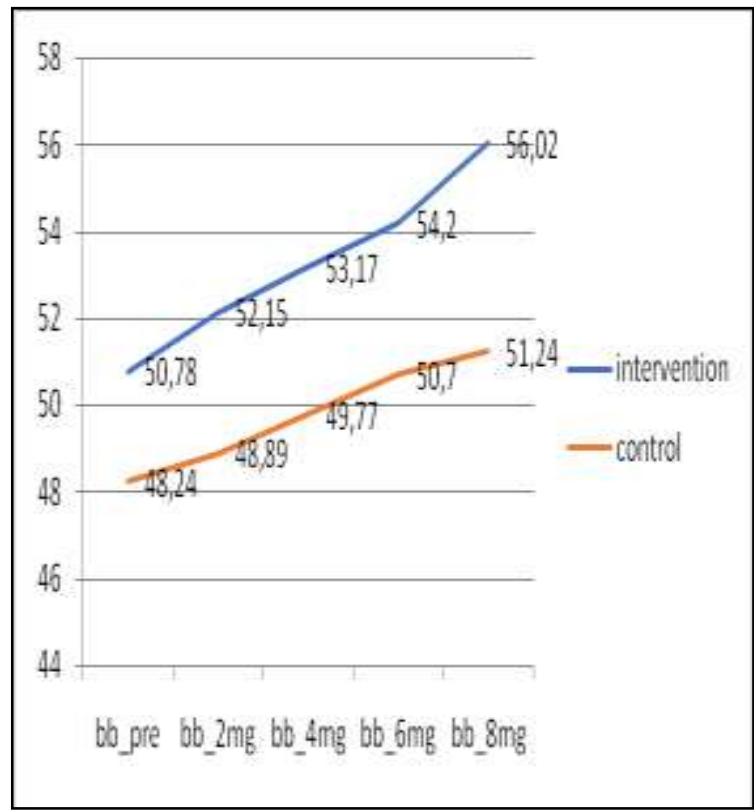

Figure.1

Nutritional weight status based on body weight before and after 2 weeks, 4 weeks, 6 weeks and 8 weeks

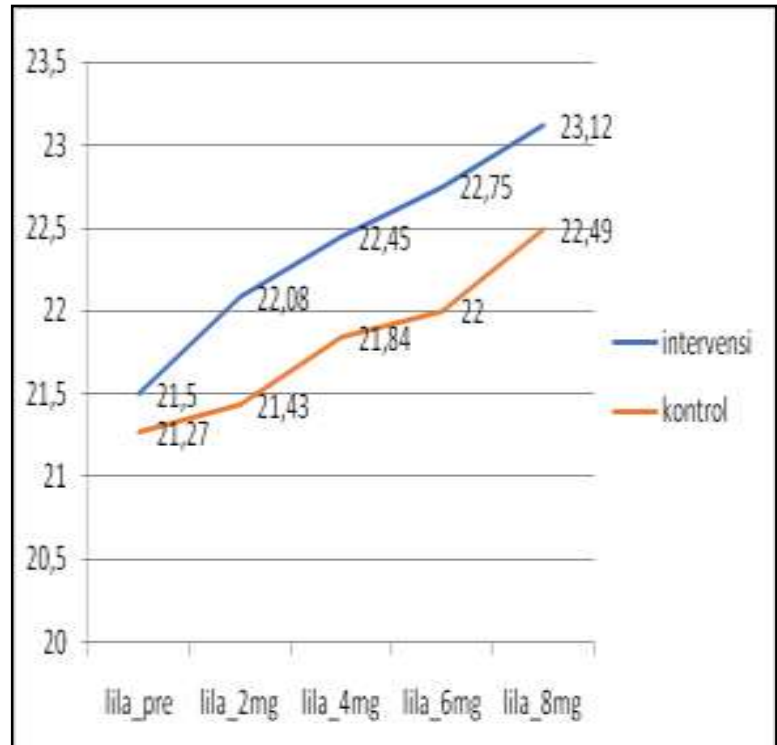

Figure 2

Mean nutritional status based on body weight before and after 2 weeks, 4 weeks, 6 weeks and 8 weeks of intervention group experienced a greater increase than the control group.

\section{Inferential Analysis}

Based on table 1 below, the results of the analysis with the $t$ test obtained a value of 1.186 <from $t$ table 1.64. This shows that Ho is accepted, which means there is no difference in body weight between the intervention group and the control group before the study was carried out.

Table 1

Analysis of weight differences between the intervention group and the control group before the study

\begin{tabular}{c|c|c|l}
\hline $\begin{array}{c}\text { Sample } \\
\text { Group }\end{array}$ & n & Mean & \multicolumn{1}{|c}{$\begin{array}{c}\text { t-test, } \\
\text { p value }\end{array}$} \\
\hline Intervensi & 18 & 50.7778 & $\begin{array}{l}\text { t test. }= \\
1.186 \\
\end{array}$ \\
& & & $\begin{array}{l}\text { P value }= \\
0,0244\end{array}$ \\
\hline
\end{tabular}

Based on table 2 below, the results of the analysis with the $t$ test obtained a value of $1.229<\mathrm{t}$ table 1.64. This shows that Ho is accepted, which means there is no difference in LBW between the intervention group and the control group before the study was conducted. Thus, there was no significant difference between the intervention group and the control group in BW and UAC, so this group was homogeneous.

Table 2

Analysis of differences in UAC between the intervention group and the control group before the study

\begin{tabular}{c|c|c|l}
\hline $\begin{array}{c}\text { Sample } \\
\text { Group }\end{array}$ & n & Mean & \multicolumn{1}{|c}{$\begin{array}{c}\text { t-test } \\
\text { p value }\end{array}$} \\
\hline Intervensi & 18 & 21,7389 & $\begin{array}{l}\mathrm{t} \text { test. }= \\
1,229 \\
\end{array}$ \\
& & & $\begin{array}{l}\text { P value }= \\
0,0244\end{array}$ \\
\hline
\end{tabular}


Based on table 3 above, the results of the analysis with the $t$ test show that after 8 weeks of intervention, the $t$ value $=9.205>t$ table 1.746. This means that Ho is rejected, there is an increase in body weight before and after being given eggs.

Table 3

Analysis of body weight before and after egg feeding in the intervention group

\begin{tabular}{l|c|c|c}
\hline $\begin{array}{c}\text { Intervention } \\
\text { Group }\end{array}$ & $\mathbf{n}$ & Mean & $\begin{array}{c}\text { t test } \\
\text { p value }\end{array}$ \\
\hline Before & 18 & 50.7778 & t test. $=-9,205$ \\
After & 18 & 56.0222 & P value $=0,000$ \\
\hline
\end{tabular}

Based on table 4 below, the results of the analysis with the $t$ test show that after 8 weeks of intervention, the $t$ value $=9.357>t$ table 1.746. This means that Ho is rejected, there is an increase in BW before and after being given eggs.

Table4

Analysis of body weight before and after giving eggs to the intervention

\begin{tabular}{l|c|c|c}
\hline $\begin{array}{c}\text { Intervention } \\
\text { Group }\end{array}$ & $\mathbf{n}$ & Mean & $\begin{array}{c}\text { t test, } \\
\text { p value }\end{array}$ \\
\hline Before & 18 & 21.5028 & t test. $=-9.357$ \\
After & 18 & 23.1194 & \multirow{2}{*}{ P value $=0,00$} \\
\hline
\end{tabular}

Based on table 5 below, the results of the analysis with the t test show that after 8 weeks without intervention, the value of $t$ count $=11,171>\mathrm{t}$ table 1,746 . This means that Ho is rejected, there is an increase in body weight in the control group.

Table 5

Analysis of body weight before and after egg feeding in the control group

\begin{tabular}{l|c|c|c}
\hline $\begin{array}{c}\text { Control } \\
\text { Group }\end{array}$ & $\mathbf{n}$ & Mean & t test, p value \\
\hline Before & 18 & 48.2389 & $\mathrm{t}$ test $=-11.171$ \\
\hline After & 18 & 51.2444 & $\mathrm{P}$ value $=0,00$ \\
\hline
\end{tabular}

Based on table 6 below, the results of the t-test analysis show that after 8 weeks without intervention, the value of $\mathrm{t}$ count $=$ $11,171>\mathrm{t}$ table 1,746 . This means that Ho is rejected, there is an increase in $\mathrm{BW}$ in the control group.

Table 6

Analysis of weight before and after offering eggs to the control group

\begin{tabular}{l|c|c|l}
\hline $\begin{array}{c}\text { Control } \\
\text { Group }\end{array}$ & $\mathbf{n}$ & Mean & t test, $\mathbf{p}$ value \\
\hline Before & 18 & 21.2667 & $\mathrm{t}$ test $=-5.127$ \\
\hline After & 18 & 22.4889 & $\mathrm{P}$ value $=0,000$ \\
\hline
\end{tabular}

Based on table 7 below, the results of the analysis with the $t$ test obtained a count value of $2.064>\mathrm{t}$ table 1.64 so that $\mathrm{Ho}$ is rejected, meaning that there is a difference in the increase in body weight between the intervention group and the control group. The average increase in body weight in the intervention group was greater than that of the control group, where the weight gain of the intervention group was 56.0222> 51.2444 .

\section{Table 7}

Post-test analysis of BW for the intervention group and the control group

\begin{tabular}{l|c|c|l}
\hline $\begin{array}{l}\text { Intervention } \\
\text { and Control }\end{array}$ & $\mathbf{n}$ & Mean & t test, $\mathbf{p}$ value \\
\hline Before & 18 & 56.0222 & $\mathrm{t}$ test $=2.064$ \\
\hline After & 18 & 51.2444 & $\begin{array}{l}\text { P value }= \\
0,047\end{array}$ \\
\hline
\end{tabular}

Based on table 8 below, the results of the analysis with the $\mathrm{t}$ test obtained the $\mathrm{t}$ value of $2.763>\mathrm{t}$ table 1.64 so that Ho was rejected, that is, there was a difference in the increase in BW between the intervention group and the control group. The average increase in BW in the intervention group was greater than that of the control group, where the BW mean of the intervention was $23.7500>22.4889$. 
Table 8

UAC post-test analysis of the intervention group and the control group

\begin{tabular}{l|c|c|c}
\hline $\begin{array}{l}\text { Intervention } \\
\text { and Control }\end{array}$ & $\mathbf{n}$ & Mean & $\mathbf{t}$ test, $\mathbf{p}$ value \\
\cline { 1 - 3 } Before & 18 & 23.7500 & $\mathrm{t}$ test $=2.763$ \\
\cline { 1 - 3 } After & 18 & 22.4889 & \multirow{2}{*}{ P value $=0,009$} \\
\hline
\end{tabular}

Based on table 9 below, with the oneway ANOVA test it is proven that there is a difference in the increase in body weight. During the 8 weeks of being given boiled eggs, body weight increased and increased significantly at week 8 .

Table 9

Analysis of the effective time of giving eggs to increase body weight using One way Anova

\begin{tabular}{l|c|c|c}
\hline \multicolumn{1}{c|}{ B W } & Mean & F & p value \\
\cline { 1 - 2 } Intervention & 56.0222 & 2.619 & 0.041 \\
\cline { 1 - 2 } Control & 51.2444 & & \\
\hline
\end{tabular}

Based on table-10 below, with the oneway ANOVA test it is proven that there is an increase in UAC increase. UAC increases occurred at week six after being given eggs and increased more significantly at week 8

Table 10

Analysis of the effective time of offering eggs to increase UAC by one way Anova

\begin{tabular}{|l|c|c|c|}
\hline \multicolumn{1}{|c|}{ LBW } & Mean & $\mathrm{F}$ & $\mathrm{p}$ value \\
\cline { 1 - 3 } Intervention & 23.119 & 7.336 & 0.000 \\
\cline { 1 - 2 } Control & 22.516 & & \\
\hline
\end{tabular}

\section{DISCUSSION}

Weight gain after consumption of boiled eggs

Body weight is a description of the amount of protein, fat, water and minerals in the bones. Body weight is related to fetal nutrition. Maternal weight before pregnancy and weight gain during pregnancy affect fetal growth(12).

The results of the study can be seen in graph 1 above, that the average body weight before the intervention, both the intervention group and the control group, has increased. However, the intervention group experienced greater weight gain than the control group. In the intervention group the average body weight before the intervention was $50.78 \mathrm{~kg}$ and after the intervention gradually increased to $52.15 \mathrm{~kg}$ at the second week, $53.17 \mathrm{~kg}$ at the fourth week, $54.2 \mathrm{~kg}$ at the sixth week, and $56.02 \mathrm{~kg}$ on the eighth week. . Whereas in the control group there was an increase that was less than the weight gain in the intervention group. In the control group the average body weight gain before intervention was $48.24 \mathrm{~kg}$, after monitoring without intervention there was an increase to $48.89 \mathrm{~kg}$ at week two, $49.77 \mathrm{~kg}$ at week four, $50.7 \mathrm{~kg}$ at week six, and $51.24 \mathrm{~kg}$ at the eighth week.

The results showed that giving one boiled egg per day could increase the weight of pregnant women in CED. Pregnant women are a group that is prone to experiencing nutritional problems. This can be dangerous not only for the mother but also for the child in her womb. A person's nutritional condition is affected by their nutritional status during pregnancy(8). The nutritional status of pregnant women greatly affects the growth of the fetus in the womb. Maternal nutritional status that is not good both before pregnancy and during pregnancy will cause Low Birth Weight (LBW)(13).

\section{Increase in UAC after consumption of boiled eggs}

UAC measurements are often used to measure the nutritional status of pregnant women. UAC is a description of the state of muscle tissue and subcutaneous fat layer. Upper Arm Circumference (UAC) is a type of anthropometric examination used to measure the risk of CED in women of childbearing age which includes adolescents, 
pregnant women, nursing mothers and couples of reproductive age (CRA). While the threshold for UAC in women with the risk of KEK is $23.5 \mathrm{~cm}$ and if it is less than $23.5 \mathrm{~cm}$ then the woman has CED(14).

The results of the study can be seen in graph 2 above, that the average LBW before the intervention both the intervention group and the control group experienced an increase. However, the intervention group experienced a greater increase in UAC than the control group. In the intervention group the average UAC before intervention was $21.5 \mathrm{~cm}$ and after intervention gradually increased to $22.8 \mathrm{~cm}$ at week two, $22.45 \mathrm{~cm}$ at week four, $22.75 \mathrm{~cm}$ at week six, and $23.12 \mathrm{~cm}$ at the eighth week. Whereas in the control group there was an increase that was less than the increase in UAC in the intervention group. In the control group the average increase in UAC before intervention was 21.27, after monitoring without intervention there was an increase to 21.43 $\mathrm{cm}$ at week two, $21.84 \mathrm{~cm}$ at week four, $22.00 \mathrm{~cm} \mathrm{~kg}$ at week six, and 22. 49 in the eighth week.

UAC measurements cannot be used to monitor changes in nutritional status in the short term(15). UAC measurement is used because the measurement is very easy and fast. There are two possible results of UAC measurements, which are less than $23.5 \mathrm{~cm}$ and above or equal to $23.5 \mathrm{~cm}$. If the measurement result is $<23.5 \mathrm{~cm}$, it means the risk of SEZ and $\geq 23.5 \mathrm{~cm}$ means there is no risk of SEZ. The results showed that giving one boiled egg per day could increase the weight of pregnant women in $\operatorname{CED}(16)$.

\section{The effect of giving boiled eggs on the nutritional status of pregnant women in CED}

Pregnancy nutrition of pregnant women is one of the determining factors that affect the birth of normal and healthy babies. During pregnancy, there is an increased need for nutrients, such as carbohydrates, protein, vitamins and minerals to meet the needs associated with changes in the mother's body and fetal development. During pregnancy, the mother will experience physical and physiological changes. In pregnancy, normal changes appear, among others, in the increase in body weight (BW) of the mother in accordance with the growth and development of the fetus, additional fat reserves, and placental development, increased body fluids and breast enlargement. In addition, due to hormonal changes, pregnant women also experience psychological, sociological and emotional changes (17).

The results of the study for eight weeks, at the second, fourth and sixth weeks there was a relationship between offering boiled eggs to the nutritional status of pregnant women in CED, both based on body weight and UAC, but it was not significant. In the eighth week there were differences in body weight and UAC with before offering boiled eggs. For eight weeks between the intervention group and the control group with $\mathrm{P}$ values (0.01 and 0.04). The difference in the increase in body weight is $5.24 \mathrm{~kg}$, the difference is UAC $1.62 \mathrm{~cm}$. where the greatest increase occurred in the intervention group and the intervention group $\mathrm{P}$ value $(0.05)$. This means that the increase in weight and UAC increases significantly in the eighth week. Thus,consuming boiled eggs, both body weight and UAC can be said to reach a significant value at the eighth week.

Chicken eggs are animal protein foods that are easy to obtain and process. Eggs are processed by boiling healthier because there is no added fat during cooking. Eggs are suitable in many methods, used as the main or side menu to snacks. Eggs are a nutritious food choice that is not rich in animal protein, but also good vitamins and minerals, namely vitamin $\mathrm{A}$, vitamin $\mathrm{B}$ complex, vitamin D, selenium, folic acid, and zinc. Eggs as a food ingredient that has many advantages, for example, the high nutritional content of eggs, the price is relatively cheap when compared to other protein sources (18). 
By consuming eggs, the intake of daily energy needs of pregnant women who are high can be met. The appetite of pregnant women who often experience changes makes eggs a nutrient-dense food choice because they tend to be quite small in size so that they are easy for pregnant women to consume when their appetite decreases(19). High calorie and protein content, consume one egg every 1 day to meet the nutritional needs of pregnant women. The results of research on the conceptual effect of boiled eggs on the increase in $\mathrm{Hb}$ levels in pregnant women in the second trimester of BPM in the working area of the Primary health care Klaten Tengah $\mathrm{The} \mathrm{Hb}$ of pregnant women between pre and post consumption of $\mathrm{Fe}$ tablets in pregnant women with consumption of boiled eggs and without consumption of boiled eggs showed a $\mathrm{p}$ value of 0.001 $(<0.05)$, which indicates a difference between the changes in pre-post pregnant $\mathrm{Hb}$ for TM II women consumption of Fe tablets between groups consuming chicken eggs. without the consumption of boiled eggs. So that consumption of boiled eggs is effective for increasing hemoglobin levels in pregnant women in the second trimester in the working area of Primary health care Klaten Tengah(20). Likewise, the research conducted by Suprapti on offering boiled eggs to postpartum mothers proved a significant difference in changes in the $\mathrm{Hb}$ levels of post-partum mothers who consumed boiled eggs in purebred chickens with post-partum mothers who did not consume boiled eggs. an increase in $\mathrm{Hb}$ levels in postpartum mothers

\section{CONCLUSION}

As above explanation, some of There was no difference in weight and UAC in the intervention group and control group before the study, but there were differences in weight and UAC before and after egg administration in the intervention and control groups, and The effective time for offering boiled eggs to increase BW and LiLA is the eighth week.

\section{REFERENCES}

1. Loya RRP, Nuryanto N. Nursury model of feeding for stunting in 6-12 months babies in Central of East Nusa Tenggara Timur: Diponegoro University; 2017 (Indonesia).

2. Putri MC. The relationship between feeding and chronic energy deficiency in women in Terbanggi Besar Sub district of Central Lampung District. 2017 (Indonesia).

3. Mahirawati VK. Factors related to chronic energy deficiency in pregnant women in Kamoning and Tambelangan Sub districts of Sampang Disctric in East Jawa. Buletin Penelitian sistem kesehatan.2014;17(2):198-9

(Indonesia).

4. Puspitaningrum EM. The relationship between nutritional status in pregnant women with Low Birth Weight in RSIA Annisa Hospital in Jambi City in 2018. Scientia Journal. 2018;7(2):17 (Indonesia).

5. Health Ministry of Republic of Indonesia. Basic Health Research in 2018. Jakarta: Health Ministry of Republic of Indonesia. 2018 (Indonesia).

6. Kendari PDKK. Southeast Sulawesi Province Profile in 2017. Kendari; Department of Health of Southeast Sulawesi. 2018 (Indonesia).

7. Health Ministry of Republic of Indonesia. Indonesian Health Profile in 2015. Jakarta: Health Ministry of Republic of Indonesia. 2015 (Indonesia).

8. Noviyanti PH. Obedity from pregnant women to consume the iron table in PMB Surabaya: Surabaya: Merdeka University. 2019 (Indonesia).

9. Sugita S, Supiati S. The effect of consuming chicken egg to increasing the Hemoglobine in pregnant women in Central Klaten Primary Health 
Centre. Jurnal Ilmu Kesehatan. 2016;5(2) (Indonesia).

10. Mackey A, Gass SM. Second language research: Methodology and design: Routledge; 2015.

11. Sugiyono. Statistik Nonparametris Untuk Penelitian. 2015.

12. Ilmiani TK. The relationship between pregnant women's knowledge with increasing body weight in Bandar Lampung Primary Health Centre. 2019 (Indonesia).

13. Sari F, Ernawati E. The relationship between mother's attitude about baby and child feeding with nutritional status in under two years old. Journal of Health (JoH). 2018;5(2):77-80 (Indonesia).

14. Thena ELM. The relationship between husband support and nutritional Status Gizi with Anemia in pregnant mother in Ladja Primary Health Centre in Ngada District of NTT: Airlangga University; 2018 (Indonesia).

15. Aini I. The relationship between Upper Arm Circle with Anemia in pregnant mother in Dukuh Klopo Primary Health Centre in Peterongan Sub District in Jombang District. Jurnal Kebidanan. 2017;7(1) (Indonesia).

16. Arliansyah ARW. The relationship between fat consuming with nutritional Status with hypertension in elderly women in Sanut Kaja Village, South Denpasar Sub District: Poltekkes Denpasar; 2019 (Indonesia).

17. Andriani Z. Overview of pregnant nutritional status based on Upper Arm Circle in Sukamaju Village of Depok City: UIN Syarif Hidayatullah Jakarta: Fakulty of Medicine and Health Sciences. 2015 (Indonesia).

18. Hardiyani AM. The effect of Cassava powder (ipomoea batatas) on egg rendang gredient: University of Negeri Jakarta. 2016 (Indonesia).

19. Rahma Cahyani D. Widwifery of children growth and malnutrition in Daya Asri Village of Daya Murni
Tulang Bawang Barat Primary Health Centre. Poltekkes Tanjung Karang; 2019 (Indonesia).

20. Lutfiasari D, Yanuaringsih GP. The effect of chicken egg consumtion on Hemoglobine in pregnant mothers. Jurnal Bidan Pintar. 2020;1(1):11-20 (Indonesia). 